\title{
Males at High Risk for Breast Cancer: Who Are They and How Should We Screen Them?
}

\author{
Natalie Swergold1 ${ }^{*}$, Vijayashree Murthy², Ronald S. Chamberlain 1,2,3 \\ ${ }^{1}$ Saint George's University School of Medicine, Grenada, West Indies \\ ${ }^{2}$ Department of Surgery, Saint Barnabas Medical Center, Livingston, USA \\ ${ }^{3}$ Department of Surgery, New Jersey Medical School, Rutgers University, Newark, USA \\ Email: nmswergs@gmail.com, drvijumurthy@gmail.com, rchamberlain@barnabashealth.org
}

Received 22 May 2014; revised 20 June 2014; accepted 15 July 2014

Copyright (C) 2014 by authors and Scientific Research Publishing Inc.

This work is licensed under the Creative Commons Attribution International License (CC BY). http://creativecommons.org/licenses/by/4.0/

(c) (i) Open Access

\section{Abstract}

Background: It is estimated that 2240 males in the United States will develop invasive breast cancer (BC) in 2013, resulting in 410 deaths. Overall, male breast cancers (MBCs) are diagnosed with larger tumor size, more frequent lymphatic invasion, and advanced tumor stage compared to their female counterparts. Several risk factors have been elucidated for the development of MBC, and this paper aims to critically review the existing literature on at-risk populations and provide screening recommendations. Methods: A comprehensive search for all published studies on populations at risk for MBC using PubMed, EBSCOhost, and Google Scholar was performed (19822013). The search focused specifically on genetic and epidemiologic risk factors, and screening for MBC. Keywords searched included "male breast cancer risk factors", "male breast cancer epidemiology", and "male breast cancer genetics". A total of 34 studies involving 4,865,819 patients were identified. Results: Five studies $(\mathrm{N}=327,667)$ focused primarily on family history of breast cancer as a risk factor for MBC. $15 \%-20 \%$ of men with $B C$ have a family history of breast or ovarian cancer, and a family history of $\mathrm{BC}$ among first-degree relatives confers a 2- to 3-fold increase in MBC risk (odds ratio $=3.3$ ). Seventeen studies $(N=5451)$ analyzed associations between several heritable genes and MBC. Lifetime MBC risk among BRCA1 mutation carriers is $1 \%-5 \%$, while MBC risk in BRCA2 mutation carriers is higher and varies between $4 \%-40 \%$. Less clear associations between MBC and PALB2, Androgen Receptor gene, CYP17, and CHEK2 mutations have also been documented. Five studies $(\mathrm{N}=16,667)$ have addressed occupational risk factors for MBC. An 8-fold increase in $\mathrm{MBC}$ is reported in males working in the cosmetic cream manufacturing, and the motor vehicle industries. A meta-analysis of 18 trials also identified electromagnetic field exposure as a potential MBC risk, though causation remains undocumented. Eleven studies $(N=4,843,598)$ analyzed the role of abnormalities in the androgen-to-estrogen ratio as a risk factor for MBC. Conditions associated with increased MBC risk include Klinefelter's syndrome (relative risk, $R R=29.64$ ), obesity $(R R=1.98)$, orchitis/epididymitis $(R R=1.84)$, and gynecomastia $(R R=5.86)$. Conclusion:

\footnotetext{
"Corresponding author.
} 
Routine screening for MBC should be considered in all high risk male populations, including those with a prior history of breast carcinoma, a strong family history of BC (defined as an affected mother or sister), a positive BRCA2 mutation status (regardless of family history), and men diagnosed with Klinefelter's syndrome, or those in the chemical or motor vehicle industries. Genetic testing for BRCA2 should be recommended for all MBC patients. Increased public and physician education on MBC is necessary to raise awareness about this rare disease and the need for screening of at-risk populations.

\section{Keywords}

\section{Male Breast Cancer Risk Factors, Carcinoma of the Male Breast, Breast Carcinoma}

\section{Introduction}

The American Cancer Society (ACS) estimated there will be 2240 new cases of male breast cancer (MBC) in the United States in 2013, and 410 males will die from this disease [1]. The Surveillance, Epidemiology, and End Results registry has recorded 5494 cases of MBC between 1973 through 2005, with a median age at diagnosis of $\sim 67$ years, and an age-specific incidence rate demonstrating a single peak age at $\sim 75$ years [2]. Male breast cancers are typically diagnosed with greater tumor size, more frequent lymphatic involvement, and advanced tumor stage compared to females, which is at least in part the result of no defined screening programs for at-risk males and almost no public education on this topic [2] [3]. Given the rarity of MBC, large-scale familial, genetic, and environmental epidemiologic studies have proven difficult to conduct. This paper critically examines the existing literature on male populations at high risk for breast cancer, and provides specific screening recommendations for these populations.

\section{Methods}

A comprehensive search of all published studies addressing populations at risk for male breast cancer was conducted using PubMed, EBSCOhost, and Google Scholar (1982-2013). The search focused specifically on genetic and epidemiologic risk factors for male breast cancer. Keywords searched included "male breast cancer risk factors", "male breast cancer epidemiology", and “male breast cancer genetics”. A total of 34 studies involving 4,865,819 patients were identified. Inclusion criteria for studies included those focusing on epidemiological considerations including age, ethnicity, socioeconomic status, and occupation, as well as more traditional risk factors such as ethnicity, family history, BRCA/other genetic mutations, and genetic syndromes.

\section{Family History of Breast Cancer}

Five studies involving 327,667 patients (Table 1) addressed the impact of positive family history on MBC. It has been estimated that $15 \%$ - $20 \%$ of all MBC patients have a family history of breast cancer, with at least one first- or second-degree relative affected by the disease [4] [5]. In an analysis of gremline mutations in 34 MBC patients, Haraldsson et al. found a positive family history of breast cancer in 13\% of MBC cases [6]. Brinton et al. conducted a prospective cohort study of 324,920 men in the National Institute of Health-AARP Diet and Health Study, of which 121 developed breast cancer ( 9 with in situ disease, 107 with invasive breast cancer, and 5 with unknown stage) [7]. The authors found an increased risk of breast cancer among men who reported breast cancer in a first-degree relative ( $\mathrm{RR}=1.92,95 \% \mathrm{CI}: 1.19$ - 3.09), and that risk was particularly increased for individuals with an affected sister $(\mathrm{RR}=2.25,95 \% \mathrm{CI}: 1.13$ - 4.47), or both an affected mother and affected sister $(\mathrm{RR}=9.73,95 \% \mathrm{CI}: 3.96$ - 23.96) [7]. Similarly, in a population-based case-control of 81 MBC cases and 1905 male controls, Johnson et al. reported an increased risk in males with an affected mother or sister (OR $=3.65$, 95\% CI: 1.62 - 8.19) [8]. In a case-control study including $21 \mathrm{MBC}$ cases and 82 controls, D’Avanzo et al. reported that a positive breast cancer family history in a female relative was associated with an increased risk of MBC, and an odds ratio of 8.5 (95\% CI: 1.1 - 69.0) [9]. Those results were confirmed by Ewertz et al. who conducted a population-based case-control study including $156 \mathrm{MBC}$ patients and 468 controls and calculated an odds ratio of 3.3 (95\% CI: 2.0 - 5.6) for males with a positive family history of breast cancer [10]. 
Table 1. Summary of all published studies evaluating family history as a risk factor for MBC* (1995-2008).

\begin{tabular}{|c|c|c|}
\hline Study, year & Patients (N) & Outcomes \\
\hline D’Avanzo, 1995 [17] & 103 & $\begin{array}{l}\text {-Study design: a case-control study of } 21 \mathrm{MBC} \text { cases and } 82 \text { controls admitted to the hospital } \\
\text { for acute, non-neoplastic, non-hormone related disease } \\
\text {-A history of BC in female relatives resulted in an MBC OR of } 8.5 \text { (95\% CI: } 1.1 \text { - 69.0) }\end{array}$ \\
\hline Haraldsson, 1998 [1] & 34 & $\begin{array}{l}\text {-Study design: analysis of germline mutations in } 34 \mathrm{MBC} \text { patients } \\
-1(14 \%) \text { out of } 7 \text { BRCA2 mutation carriers had a positive family history of BC } \\
-13 \% \text { of cases overall had a positive family history of BC }\end{array}$ \\
\hline Ewertz, 2001 [23] & 624 & $\begin{array}{l}\text {-Study design: population-based case-control study of } 156 \text { cases and } 468 \text { controls } \\
\text {-Increased risk of MBC associated with BC family history (OR = 3.3; 95\% CI: } 2.0 \text { - 5.6) }\end{array}$ \\
\hline Johnson, 2002 [25] & 1986 & $\begin{array}{l}\text {-Study design: analysis of risk factors in a population-based case-control study of } 81 \text { newly } \\
\text { diagnosed, histologically confirmed MBC cases and } 1905 \text { male controls } \\
\text {-Increased breast cancer risk seen in men with a mother or sister with BC (adjusted OR = 3.65, } \\
\text { 95\% CI: } 1.62 \text { - 8.19) }\end{array}$ \\
\hline Brinton, 2008 [16] & 324,920 & $\begin{array}{l}\text {-Study design: prospective National Institutes of Health-AARP Diet and Health Study, of } \\
\text { 324,920 men, among whom } 121 \text { developed breast cancer. } \\
\text {-Men with a first-degree relative with BC had an increased risk of breast cancer (RR = 1.92, } \\
\text { 95\% CI: } 1.19 \text { - 3.09) }\end{array}$ \\
\hline
\end{tabular}

Abbreviations: $\mathrm{OR}$ = odds ratio, $\mathrm{CI}$ = confidence interval, $\mathrm{MBC}=$ male breast cancer, $\mathrm{AR}$ = androgen receptor gene, $\mathrm{BRCA}=$ breast cancer gene, $\mathrm{RR}$ $=$ relative risk.

\section{Genetic Mutations}

Seventeen studies involving a total of 5451 patients (Table 2) analyzed the associations between heritable genetic mutations and the development of MBC. Identified cancer susceptible genes include BRCA1/2, PALB2, AR gene, and CHEK2 mutations, as well as CYP17 promotor polymorphisms [3] [4] [6] [11]-[24].

\subsection{BRCA Gene Mutations}

The BRCA genes are classified as tumor-suppressor genes, in that they maintain genomic stability and cell-cycle checkpoint control [25]. Mutations in the BRCA1/2 genes results in cancer initiation, and the subsequent accumulation of genetic mutations and instabilities can ultimately engender cancer development [25]. The reported frequencies of BRCA2 germ-line mutations in MBC vary between populations, likely due to small sample sizes and varying methodologies and sensitivities of mutation screening methods [24]. Friedman et al. analyzed 54 cases of MBC from a Southern-California population and identified only 2 (4\%) carriers [4]. Contrarily, Thorlacius et al. [11] reported that $40 \%$ of all MBC cases diagnosed in Iceland over a period of 40 years carried a specific BRCA2 mutation (999del5), and Couch et al. [12] reported a 14\% mutation rate in their study of 50 MBC patients. Mavraki et al. screened DNA from 26 males affected with breast cancer, and identified 3 pathogenic mutations, all of which resulted in premature termination of translation, and calculated a $7 \%-11 \%$ frequency of BRCA2 germ-line mutations [17]. In a population-based study of $94 \mathrm{MBC}$ cases, Basham et al. identified 5 pathogenic mutations in BRCA2 and calculated a 6\% carrier frequency of BRCA2 mutations (95\% CI: 2 - 13) [19]. In a retrospective study of 97 men with breast carcinoma, Tai et al. estimated a $6.8 \%$ cumulative risk of MBC for BRCA2 mutation carriers at 70 years of age (95\% CI: 3.2 - 12) [22]. Risch et al. observed an increased MBC relative risk of 102 for BRCA2 mutation carriers versus non-carriers (95\% CI: 9.9 - 1.050) [23]. Syrjakoski et al. screened a cohort of $154 \mathrm{MBC}$ patients for BRCA2 mutations, and identified previously described founder or novel mutations in 12 (7.8\%) cases [18]. Additionally, the authors found that $44 \%$ of patients with a positive family history of breast cancer carried a BRCA2 mutation, as compared to the $3.6 \%$ of patients without a family history $(p<0.0001)$ [18]. However, this positive association between family history and BRCA mutation carrier status has not been reproduced in other analysis. While Haraldsson et al. identified BRCA2 germ-line mutations in 7 (20.6\%) of 34 cases and estimated a case mutation frequency of $16 \%$, 86\% of MBC cases carrying BRCA2 mutations had no family history of breast cancer [6]. Similarly, Ding et al. identified pathogenic BRCA2 mutations in 18 of $115 \mathrm{MBC}$ cases, resulting in a BRCA2-mutation prevalence of 16\% (95\% CI: 11 - 24), though the difference in BRCA2-mutation frequencies between cases with and without family history of breast cancer was not statistically significant ( $p=0.145$ ), further indicating that family history is a weak predictor of mutation carrier status in males [15]. Moreover, Ottini et al. [26] reported that 50\% of BRCA2 pathogenic mutations were in 
Table 2. Summary of all published studies evaluating genetic mutations as a risk factor for MBC* (1996-2011).

\begin{tabular}{|c|c|c|}
\hline Study, year & Patients (N) & Outcomes \\
\hline Couch, 1996 [4] & 50 & $\begin{array}{l}\text {-Study design: germline DNA from } 50 \text { MBC cases (unselected for family history) } \\
\text { analyzed for mutations in BRCA2 } \\
\text {-9 disease-associated mutations detected, with } 7 \text { of } 9 \text { seen in the } 50 \text { MBC cases } \\
\text {-BRCA2 mutations estimated to account for } 14 \% \text { of MBC, all but one of which had a } \\
\text { family history of male and/or female breast cancer }\end{array}$ \\
\hline Thorlacius, 1996 [2] & 9 & $\begin{array}{l}\text {-Study design: } 9 \text { families with a history of MBC studied to determine linkage between } \\
\text { BRCA2 and hereditary MBC } \\
\text {-Among mutation carriers, there are } 12 \text { MBC cases, accounting for } 40 \% \text { of all males } \\
\text { diagnosed with breast cancer in Iceland over the past } 40 \text { years } \\
\text {-3 (25\%) of the } 12 \text { cases had no family history of breast cancer (no statistical significance } \\
\text { reported) }\end{array}$ \\
\hline Friedman, 1997 [3] & 54 & $\begin{array}{l}\text {-Study design: population-based series of } 54 \text { MBC cases analyzed for germline mutations } \\
\text { in BRCA1/2 } \\
\text {-No germline BRCA1 mutations found } \\
\text {-2 (4\%) MBC cases carried truncating BRCA2 mutations, and only } 1 \text { of those carrying a } \\
\text { mutation had a family history of cancer (ovarian cancer in a first-degree relative) }\end{array}$ \\
\hline Mavraki, 1997 [11] & 26 & $\begin{array}{l}\text {-Study design: screening of DNA from } 26 \text { MBC cases to determine the frequency of } \\
\text { BRCA2 germline mutations } \\
\text {-BRCA2 mutation detected in } 3(12 \%) \text { out of } 26 \text { cases } \\
\text {-3 mutations resulting in frameshifts and premature termination of translation identified }\end{array}$ \\
\hline Haraldsson, 1998 [1] & 34 & $\begin{array}{l}\text {-Study design: the coding region of the BRCA2 and AR genes in breast tumors from } 34 \\
\text { MBC patients were analyzed } \\
\text {-No cases of germline AR mutations were observed, but the number of AR polyglutamine } \\
\text { repeats were lower among BRCA mutation carriers } \\
\text {-5 different BRCA2 germline mutations were seen in } 7(20.6 \%) \text { of the } 34 \text { cases, all of } \\
\text { which resulted in the formation of truncated protein products }\end{array}$ \\
\hline Csokay, 1999 [9] & 18 & $\begin{array}{l}\text {-Study design: a series of } 18 \text { MBC patients analyzed for germ-line mutations in BRCA1/2 } \\
\text {-No germline BRCA1mutation was observed } \\
-6(33 \%) \text { of the } 18 \text { MBC cases carried truncating mutations in the BRCA2gene and none of } \\
\text { them reported a family history for breast/ ovarian cancer } \\
\text {-4 (22\%) patients had a family history of breast/ovarian cancer in } \geq 1 \text { first- or } \\
\text { second-degree relative; no BRCA2mutation was detected among them }\end{array}$ \\
\hline Young, 2000 [5] & 145 & $\begin{array}{l}\text {-Study design: case-control study of } 64 \text { cases and } 81 \text { controls to investigate whether } \\
\text { increased length of CAG repeat sequence in AR is associated with development of MBC } \\
\text {-There was no statistical significance in the distribution of CAG repeats in AR among } \\
\text { MBC cases and controls ( } p=0.916 \text { ) } \\
\text {-No difference between median CAG repeat length of cases and controls ( } p=0.765) \\
\text {-Sequences of } \geq 30 \text { repeats were found only among cases }\end{array}$ \\
\hline Basham, 2002 [22] & 94 & $\begin{array}{l}\text {-Study design: population-based study of } 94 \mathrm{MBC} \text { aimed to establish to prevalence of } \\
\text { BRCA1 and BRCA2 mutations } \\
\text {-No disease-associated mutations were identified in BRCA1 } \\
\text {-5 disease-associated variants were seen in BRCA2 } \\
\text {-The carrier frequency of BRCA2 mutations was } 6 \% \text { (95\% CI: } 2 \text { - 13) }\end{array}$ \\
\hline Frank, 2002 [33] & 76 & $\begin{array}{l}\text {-Study design: prevalence of germline mutations in BRCA1/2 analyzed in } 76 \text { MBC cases } \\
\text {-Deleterious mutations were seen in } 21 \text { ( } 28 \% \text { ) of } 76 \text { cases, with } 8 \text { mutations occurring in } \\
\text { BRCA1 and } 14 \text { in BRCA2(one Ashkenazi individual had one mutation in each gene) } \\
\text {-No statistical significance in mutation prevalence in men with a family history of breast or } \\
\text { ovarian cancer versus those without } \\
\text {-No statistical significance in mutation prevalence in MBC patients of Ashkenazi ancestry } \\
\text { compared with those of non-Ashkenazi ancestry }\end{array}$ \\
\hline $\begin{array}{c}\text { Meijers-Heijboer, } 2002 \\
{[29]}\end{array}$ & 2691 & $\begin{array}{l}\text {-Study design: genome-wide linkage search of } 718 \text { families in which breast cancer } \\
\text { susceptibility is not due to BRCA mutation } \\
\text {-CHEK } 2 * 1100 \text { delC variant in } 13.5 \% \text { of patients from families with MBC ( } p=0.00015 \text { ) } \\
\text {-CHEK } * 1100 \text { delC variant results in an } \sim 10 \text {-fold increase of MBC risk in non-carriers of } \\
\text { BRCA } 1 \text { and BRCA2 mutations (statistical significance not reported) } \\
-9 \% \text { of MBC cases attributable to CHEK } 2 * 1100 \text { delC (statistical significance not reported) }\end{array}$ \\
\hline
\end{tabular}




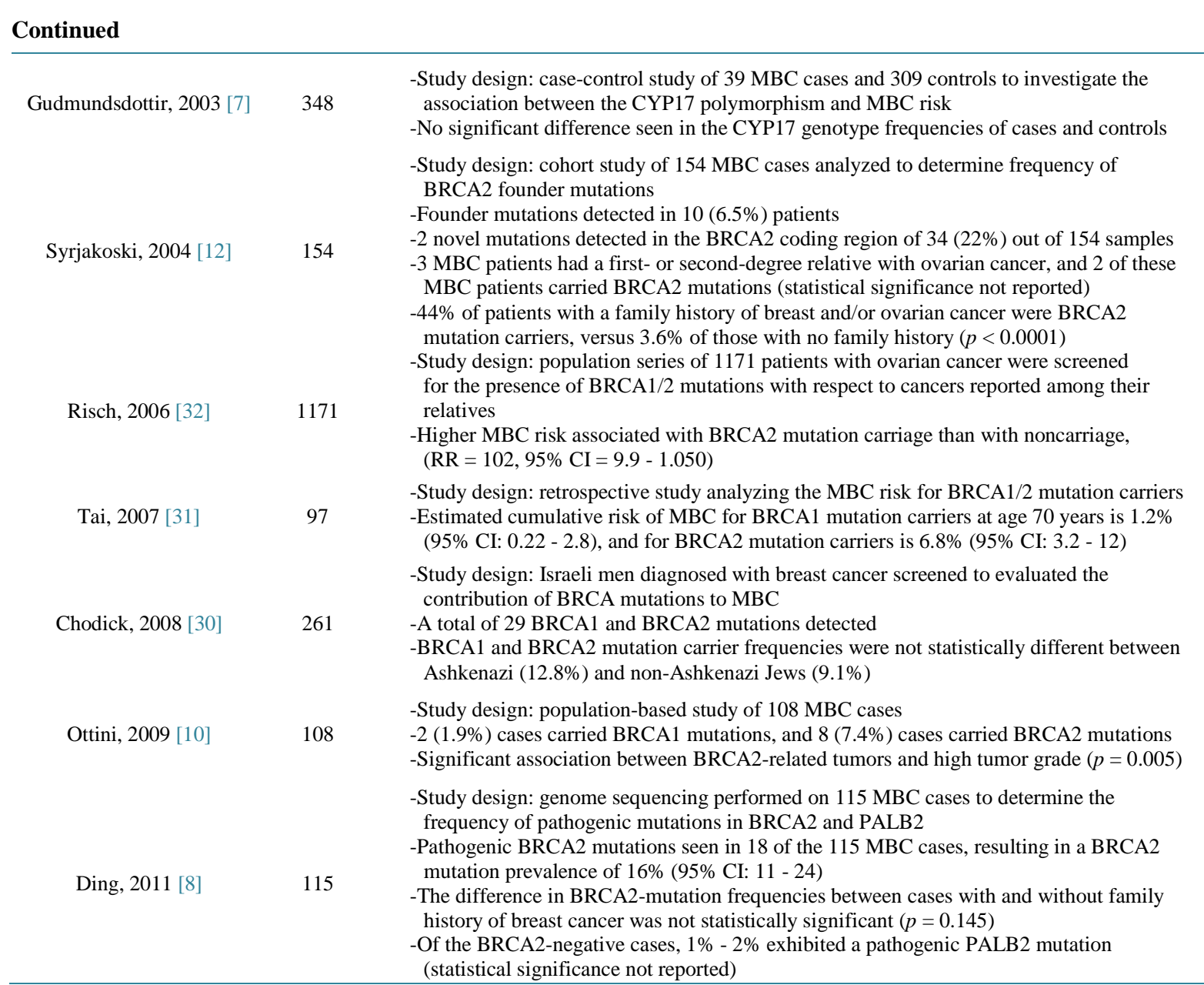

Abbreviations: $\mathrm{MBC}=$ male breast cancer, $\mathrm{AR}=$ androgen receptor gene, $\mathrm{BRCA}=$ breast cancer gene, $\mathrm{CI}=$ confidence interval, $\mathrm{PALB} 2=$ partner and localizer of BRCA2 gene. ${ }^{*} p$ value: statistical significance, $<0.05$.

MBC cases without a family history of breast cancer, and Csokay et al. [16] found that 0 of 6 MBC cases with pathogenic BRCA2 mutations had a family history of breast cancer. In an analysis of 76 men with breast cancer, Frank et al. identified deleterious mutations in $28 \%$ of the cases, of which more than one-third occurred in BRCA1 [24]. These mutations were more prevalent in men with a family history of breast or ovarian cancer and in men of Ashkenazi ancestry, although these findings failed to achieve statistical significance $(p=0.1121$ and $p$ $=0.1117$, respectively) [24]. In an analysis of 261 Israeli men with a diagnosis of breast cancer, Chodick et al. observed no difference in the BRCA1 or BRCA2 mutation carrier frequencies between Ashkenazi and nonAshkenazi Jews, implicating that the increased incidence of MBC observed in Ashkenazi men cannot be accounted for by the prevalence of BRCA1/2 mutations alone [21]. Failure of BRCA mutation prevalence to reach statistical significance in men of Ashkenazi heritage is in stark contrast to the prevalence observed in their female counterpart. The prevalence of BRCA1andBRCA2 mutations among Caucasian non-Ashkenazi Jewish women with breast cancer is $2.2 \%-2.9 \%$ and $2.2 \%$, respectively, and $8.3 \%-10.2 \%$ and $1.1 \%$, respectively, among Ashkenazi Jewish women with breast cancer [25] [27]. While the prevalence of BRCA1 and BRCA2 mutations among African American women with breast cancer is noted to be $1.3 \%-1.4 \%$ and $2.6 \%$, respectively [25] [27], the prevalence among the male African American population has yet to be specifically analyzed. However, the incidence of breast cancer is higher among black men of all ages $(1.8$ per 100,000) when compared to their age-related white counterparts (1.1 per 100,000), and afflicted black males display poorer prognostic features, including advanced-stage disease, with more extensive nodal involvement, larger tumor sizes, and higher tumor grade [2]. While racial disparities in outcomes in women with breast cancer are well studied, those in men warrant further investigation. 


\subsection{Other Genes Associated with MBC}

Various additional genetic mutations have been implicated in the development of male breast cancer, however these mutations account for far less cases than the previously discussed BRCA1/2 mutations. The PALB2 gene product plays a role in the localization and stabilization of BRCA2 in nuclear chromatin, which is essential for BRCA2 to function in DNA repair. Ding et al. postulated that PALB2 may confer risk to develop MBC as a result of its close relationship to BRCA2 [15]. The authors screened for mutations in the PALB2 gene in BRCA2negative MBC cases and identified 14 germ-line variants, which accounted for $1 \%$ - $2 \%$ of male breast cancers [15]. The CYP17 gene codes for an enzyme involved in the synthesis of androgens and estrogens. A known single base pair polymorphism creates an additional promotor motif, which has been hypothesized to lead to increased transcriptional activity and enhanced steroid hormone production. That said, Gudmundsdottir et al. investigated the association between CYP17 polymorphism and male breast cancer risk and found no difference in genotype frequencies between MBC cases and controls [14]. The CHEK2 gene located on chromosome 22 encodes a cell-cycle checkpoint kinase that is implicated in DNA repair processes involving BRCA1 and p53. Meijers-Heijboer et al. showed that a known truncating variant of the gene has a frequency of $1.1 \%$ in healthy individuals, but is present in $13.5 \%$ of individuals from families with male breast cancer $(p=0.00015)$ [20]. The authors estimated that this CHEK2 variant confers an 10 -fold increase in the risk of MBC that may account for $\sim 9 \%$ of male breast cancers [20]. Haraldsson et al. surmised that mutant Androgen Receptor (AR) genes may exhibit an altered sequence-specific DNA binding, possibly having acquired the ability to bind to estrogenresponsive elements and to activate estrogen-regulated genes, though they found no evidence of germ-line or somatic AR mutations among $34 \mathrm{MBC}$ cases [6]. A region within exon 1 of the gene coding for the AR is highly polymorphic and contains a variable number of CAG repeats, with in vitro studies revealing that a short CAG repeat sequence increases the level of transactivation of the androgen receptor [13]. Young et al. investigated whether increased length of the CAG repeat sequence in the AR gene is associated with the development of MBC [13]. While the authors did not observe a significant overall difference between the median number of CAG repeat length of MBC cases and controls, sequences of 30 or more repeats were only observed in MBC cases, leading the authors to surmise that a relatively long CAG repeat sequence within the AR gene may be implicated in MBC, and a short sequence may offer protection against MBC [13].

\section{Occupational Exposures}

Five studies involving a total of 16,667 patients (Table 3) have addressed occupational exposure as a risk factor from MBC. McLaughlin et al. assessed the incidence of male breast cancer by occupational and industrial categories to elucidate environmental and occupational risk factors [28]. Those industries and occupations with a significantly $(p<0.05)$ increased incidence of male breast cancer were determined from a sample of 333 cases of male breast cancer [28]. The highest risk ( 8-fold) was observed in men employed in making soap and perfume, which the authors attributed to the production of estrogen-containing cosmetic creams by this population [26]. A meta-analysis of 7 case-control and 11 cohort studies by Sun et al. revealed a statistically significant increased risk of MBC with electromagnetic field exposure as well (pooled ORs $=1.32,95 \% \mathrm{CI}=1.14-1.52, p<$ 0.001), and subgroup analyses also showed similar results [29]. Cocco et al. conducted a case-control of 178 MBC cases and 1041 controls to investigate whether risk of MBC is associated with workplace exposures [30]. A significant risk in MBC was associated with employment in blast furnaces, steel works, rolling mills (OR = 3.4, 95\% CI: 1.1 - 10.1), and motor vehicle manufacturing (OR = 3.1, 95\% CI: 1.2 - 8.2), however the authors did not hypothesize a cause for this association [30]. A case-control study of $104 \mathrm{MBC}$ cases and 1901 controls by Villeneuve et al. failed to confirm the elevated risk of MBC in blast furnaces, steel works, and rolling mills [31]. However, these authors noted a two-fold increase in MBC incidence among motor vehicle mechanics (95\% CI: 1.0 - 4.4), with a dose-response relationship related to duration of employment (OR = 5.9 in motor vehicle mechanics employed for 10 or more years, 95\% CI: 2.4 - 14.6) [31]. Furthermore, a significantly increased odds ratio of 1.8 was observed in those cases employed in the motor vehicle sales and repairs industry (95\% CI: 1.0 3.2) [31]. Similarly, Hansen reported a MBC odds ratio of 2.5 for males employed in trades with potential exposure to gasoline and combustion products for a period of more than 3 months (95\% CI: 1.3 - 4.5), and an odds ratio of 5.4 among men younger than 40 years of age at the time of first employment (95\% CI: 2.4 - 11.9) [32]. The consistently elevated risk of MBC reported in the MVI may suggest the presence of mammary carcinogens in gasoline vapors, and further investigation is warranted. 
Table 3. Summary of all published studies evaluating occupational exposure as a risk factor for MBC* (1988-2013).

\begin{tabular}{|c|c|c|}
\hline Study, year & Patients (N) & Outcomes \\
\hline McLaughlin, 1988 [6] & 333 & $\begin{array}{l}\text {-Study design: systematic review of } 333 \mathrm{MBC} \text { cases to assess the incidence by } \\
\text { occupational and industrial categories } \\
\text {-The highest occupational risk (SIR }=7.6 \text { ) was seen in men employed in the soap- and } \\
\text { perfume-making industry }(p<0.01)\end{array}$ \\
\hline Соссо, 1998 [21] & 1219 & $\begin{array}{l}\text {-Study design: case-control study of } 178 \text { cases of MBC and } 1041 \text { controls to investigate } \\
\text { risk of MBC with workplace exposures } \\
\text {-Increase in MBC risk associated with employment in blast furnaces, steel works, and } \\
\text { rolling mills (OR = 3.4, 95\% CI: } 1.1 \text { - 10.1) } \\
\text {-Increase in MBC risk associated with employment in the MVI } \\
(\mathrm{OR}=3.1,95 \% \text { CI: } 1.2 \text { - 8.2) }\end{array}$ \\
\hline Hansen, 2000 [28] & 13,110 & $\begin{array}{l}\text {-Study design: case-control study of } 230 \text { cases and } 12,880 \text { controls on the association } \\
\text { between MBC morbidity and occupational exposure } \\
\text {-OR = } 2.5 \text { ( } 95 \% \text { CI: } 1.3 \text { - } 4.5 \text { ) for men with }>3 \text { months of employment in occupations } \\
\text { with potential exposure to gasoline and combustion products } \\
\text {-OR = } 5.4 \text { for men employed at < } 40 \text { years of age ( } 95 \% \text { CI: } 2.4 \text { - 11.9) }\end{array}$ \\
\hline Villeneuve, 2010 [27] & 2005 & $\begin{array}{l}\text {-Study design: investigation of MBC occupational risk factors in a case-control study of } \\
104 \text { cases and } 1901 \text { controls } \\
\text {-Increased MBC risk in motor vehicle mechanics (OR = 2.1, 95\% CI: } 1.0 \text { - 4.4), with } \\
\text { increased risk if employed } \geq 10 \text { years (OR }=5.9,95 \% \text { CI: } 2.4-14.6) \\
\text {-Increased risk in sale/repair of motor vehicles (OR = 1.8, } 95 \% \text { CI: } 1.0-3.2)\end{array}$ \\
\hline Sun, 2013 [34] & Meta-analysis & $\begin{array}{l}\text {-Study design: a meta-analysis of } 7 \text { case-control and } 11 \text { cohort studies to confirm a } \\
\text { possible association between MBC and EMF exposure } \\
\text {-Increased risk of MBC with EMF exposure was defined } \\
\text { (pooled ORs }=1.32,95 \% \text { CI: } 1.14-1.52, p<0.001 \text { ) }\end{array}$ \\
\hline
\end{tabular}

Abbreviations: $\mathrm{MBC}=$ male breast cancer, $\mathrm{SIR}=$ standardized incidence ratio, $\mathrm{EMF}=$ electromagnetic field, $\mathrm{MVI}=$ motor vehicle industry, $\mathrm{OR}=$ odds ratio, $\mathrm{CI}=$ confidence interval. ${ }^{*} p$ value: statistical significance, $<0.05$.

\section{Abnormalities in the Androgen-to-Estrogen Ratio}

Eleven studies including a total of 4,843,598 patients (Table 4) assessed the risk of MBC in the setting of abnormal androgen-to-estrogen ratios. Nirmul et al. examined the endocrine profiles of $8 \mathrm{MBC}$ patients compared to 8 healthy matched controls [33]. These authors found that the mean total serum estradiol level and the calculated mean free estradiol index were significantly increased in MBC cases compared to controls $(p<0.01$ and $p$ $<0.01$, respectively) [33]. The two groups showed no significant differences in the levels of luteinizing hormone, follicle stimulating hormone, prolactin, dehydroepiandrosterone-sulfate, testosterone, or sex-hormone binding globulin [33]. Brinton et al. conducted an analysis within the U.S. Veterans Affairs (VA) medical care system database involving a total of 4,501,578 patients, from which they identified 642 MBC cases [34]. Medical conditions significantly associated with increased MBC risk in decreasing order were Klinefelter's syndrome (RR = 29.64, 95\% CI: 12.26 - 71.68), gynecomastia (RR = 5.86, 95\% CI: 3.74 - 9.17), obesity (RR = 1.98, 95\% CI: 1.55 - 2.54), orchitis/epididymitis ( $\mathrm{RR}=1.84,95 \% \mathrm{CI}: 1.10$ - 3.08), and diabetes $(\mathrm{RR}=1.30,95 \% \mathrm{CI}: 1.05$ 1.60) [34]. After adjusting for obesity, the association with diabetes disappeared, but that with gynecomastia persisted [34]. Notably, additional studies by Casagrande et al. [35] ( $\mathrm{N}=150)$ and Hsing et al. [36] $(\mathrm{N}=690)$ have negated the significance of the association between gynecomastia and MBC, and Olsson et al. [37] observed no new cases of MBC in a cohort of 446 men with a diagnosis of gynecomastia after a maximum followup time of 30 years. The association between increased MBC risk and obesity has been further supported by Brinton et al. in their prospective analysis of 324,920 men, including a total of $121 \mathrm{MBC}$ cases $(\mathrm{RR}=1.79,95 \%$ CI: 1.10 - 2.91, for body mass indices, BMI, of $\geq 30$ versus $<25 \mathrm{~kg} / \mathrm{m}^{2}$ ) [7]. These authors additionally noted that physical activity during adolescence was inversely associated with MBC risk (for activity $\geq 5$ times per week, $\mathrm{RR}=0.59,95 \% \mathrm{CI}: 0.31-1.13$ ), and that subjects who had a physically active routine were at a statistically significant lower risk of MBC $(\mathrm{RR}=0.49,95 \% \mathrm{CI}$ : $0.28-0.87)$ [7]. Casagrande et al. similarly observed a significant increase in relative risk of breast cancer with increasing weight recorded at age 30 in their case-control study of 75 MBC patients [35]. Men who weighed 90 or more kilograms at age 30 years had more than 5 times 
Table 4. Summary of all published studies evaluating androgen-to-estrogen ratio abnormalities as a risk factor for MBC ${ }^{*}$ (1982-2010).

\begin{tabular}{|c|c|c|}
\hline Study, year & Patients (N) & Outcomes \\
\hline $\begin{array}{l}\text { Nirmul, } 1982 \\
{[14]}\end{array}$ & 16 & $\begin{array}{l}\text {-Study design: case-control of } 8 \text { MBC cases of ductal carcinoma and } 8 \text { controls to analyze the } \\
\text { sex-hormone profile of MBC patients } \\
\text {-No significant difference in the mean fasting levels and ranges of LH, FSH, PRL, DHEA-S, and } \\
\text { SHBG in the cases when compared to the controls } \\
\text {-Mean total serum estradiol-17 } \beta \text { level and calculated mean free estradiol index increased in cases } \\
(p<0.02)\end{array}$ \\
\hline $\begin{array}{l}\text { Casagrande, } \\
1988[18]\end{array}$ & 150 & $\begin{array}{l}\text {-Study design: case-control of } 75 \text { cases and } 75 \text { controls to investigate suspected risk factors } \\
\text {-Men who weighed } \geq 90 \mathrm{~kg} \text { at age } 30 \text { had }>5 \mathrm{x} \text { the breast cancer risk of men weighing }<60 \mathrm{~kg} \text { at that age } \\
(\mathrm{RR}=5.45 \text { and } \mathrm{RR}=1.00 \text {, respectively, } p=0.04) \\
\text {-No significant difference observed between cases and controls with respect to frequency of alcohol } \\
\text { consumption } \\
\text {-Gynecomastia was not found to be a significant risk factor }\end{array}$ \\
\hline $\begin{array}{l}\text { Hsing, } 1998 \\
{[19]}\end{array}$ & 690 & $\begin{array}{l}\text {-Study design: case-control study of } 178 \mathrm{MBC} \text { mortalities and } 512 \text { male controls who died of other } \\
\text { causes to investigate risk factors } \\
\text {-Increased risk for men described as having been very overweight }(\mathrm{OR}=2.3,95 \% \mathrm{CI}: 1.1-5.0) \\
\text {-Dose-response relationship seen between risk and BMI }(p<0.01) \\
\text {-No association found for alcohol use }\end{array}$ \\
\hline $\begin{array}{l}\text { Sorensen, } 1998 \\
\quad[20]\end{array}$ & 11,642 & $\begin{array}{l}\text {-Study design: males with a diagnosis of liver cirrhosis followed for a mean of } 4.3 \text { years to assess risk } \\
\text { of breast cancer and men with cirrhosis } \\
-3 \text { cases observed (SIR }=4.0,95 \% \text { CI: } 0.8-11.7 \text { ) }\end{array}$ \\
\hline $\begin{array}{l}\text { Ewertz, } 2001 \\
\quad[23]\end{array}$ & 624 & $\begin{array}{l}\text {-Study design: population-based case-control study of } 156 \text { cases and } 468 \text { controls } \\
\text {-Increased risk of MBC associated with obesity } 10 \text { years before diagnosis }(\mathrm{OR}=2.1 \text {; } \\
\text { 95\% CI: } 1.0-4.5) \text {, and diabetes (OR = 2.6, 95\% CI: } 1.3-5.3)\end{array}$ \\
\hline $\begin{array}{l}\text { Altinli, } 2002 \\
\quad[24]\end{array}$ & 40 & $\begin{array}{l}\text {-Study design: retrospective review of all MBC patients who underwent surgery to examine relation } \\
\text { between BMI and MBC } \\
\text {-Average BMI = } 26.54 \mathrm{~kg} / \mathrm{m}^{2} \text { (above the World Health Organization upper limit of normal) } \\
\text {-23 ( } 57.5 \% \text { ) out of } 40 \text { patients were above their ideal body weight (statistical evaluation not performed } \\
\text { due to small sample size) }\end{array}$ \\
\hline $\begin{array}{l}\text { Johnson, } 2002 \\
{[25]}\end{array}$ & 1986 & $\begin{array}{l}\text {-Study design: analysis of risk factors in a population-based case-control study of } 81 \text { newly diagnosed, } \\
\text { histologically confirmed MBC cases and } 1905 \text { male controls } \\
\text {-Increased risk of MBC in overweight cases (OR = 2.19, 95\% CI: } 1.08-4.43)\end{array}$ \\
\hline $\begin{array}{l}\text { Olsson, } 2002 \\
\quad[26]\end{array}$ & 446 & $\begin{array}{l}\text {-Study design: prospective cohort study of men with histological diagnosis of gynecomastia } \\
\text {-No new cases of MBC seen at the end of median follow-up time (266 months) }\end{array}$ \\
\hline $\begin{array}{l}\text { Guenel, } 2004 \\
\quad[13]\end{array}$ & 1506 & $\begin{array}{l}\text {-Study design: case-control study of } 74 \text { histologically verified MBC cases and } 1432 \text { age-matched } \\
\text { controls to investigate the role of alcohol drinking in MBC } \\
\text {-Risk of MBC increased by } 16 \%(95 \% \text { CI: } 7 \text { - 26) per } 10 \text { grams of alcohol per day }(p<0.001) \\
\text {-OR = } 5.89 \text { (95\% CI: } 2.21 \text { - 15.69) for alcohol intake }>90 \text { grams/day }\end{array}$ \\
\hline $\begin{array}{c}\text { Brinton, } 2008 \\
{[16]}\end{array}$ & 324,920 & $\begin{array}{l}\text {-Study design: prospective NIH-AARP Diet and Health Study, of } 121 \text { MBC patients } \\
\left.\text {-Obesity was positively related to risk (RR }=1.79,95 \% \text { CI: } 1.10-2.91 \text {, for BMI }>30 \mathrm{vs}<5 \mathrm{~kg} / \mathrm{m}^{2}\right) \text { and } \\
\text { physical activity inversely related, even after adjustment for BMI }\end{array}$ \\
\hline $\begin{array}{c}\text { Brinton, } 2010 \\
\text { [15] }\end{array}$ & $4,501,578$ & $\begin{array}{l}\text {-Study design: MBC etiologic factors assessed from } 642 \text { cases of primary MBC documented in the U.S. } \\
\text { Veterans Affairs medical care database } \\
\text {-Medical conditions related to MBC risk: diabetes (RR = 1.30, 95\% CI: } 1.05-1.60) \text {, obesity }(1.98,1.55 \\
\text { - 2.54), orchitis/epididymitis }(1.84,1.10 \text { - 3.08), Klinefelter's syndrome (29.4, } 12.26 \text { - 71.68), } \\
\text { gynecomastia (5.86, } 3.74-9.17) \\
\text {-Cholelithiasis an MBC risk for black patients (RR = 3.45, 95\% CI: } 1.59-7.47) \\
\text {-After adjusting for obesity, the association between MBC and diabetes disappeared, but that between } \\
\text { MBC and gynecomastia persisted }\end{array}$ \\
\hline
\end{tabular}

Abbreviations: $\mathrm{MBC}=$ male breast cancer, $\mathrm{BMI}=$ body mass index, $\mathrm{NIH}=$ national institutes of health, $\mathrm{RR}=$ relative risk, $\mathrm{CI}=\mathrm{confidence}$ interval, $\mathrm{OR}=$ odds ratio, $\mathrm{LH}=$ luteinizing hormor, FSH = follicle stimulating hormone, PRL = prolactin, DHEA-S = dehydroepiandrosterone sulfate, SHBG $=$ sex hormone-binding globulin, $\mathrm{SIR}=$ standardized incidence ratio. ${ }^{*} p$ value: statistical significance, $<0.05$.

the risk of breast cancer than men weighing less than 60 kilograms at that age $(\mathrm{RR}=5.45$ and $\mathrm{RR}=1.00$, respectively, $p=0.04)$ [35]. In a case-control study of 178 men who died of breast cancer, Hsing et al. reported an increased risk of MBC for men who were described by their next-of kin as very overweight $(\mathrm{OR}=2.3$, 95\% CI: 1.1 - 5.0) [36]. Similarly, Ewertz et al. [10] $(\mathrm{N}=624)$ reported an increased risk of MBC in males whose BMI 
exceeded 30 ten years prior to diagnosis ( $\mathrm{OR}=2.1$, 95\% CI: 1.0 - 4.5), and Altinli et al. [38] observed an average BMI of 26.54 in 40 MBC patients, with 23 (57.5\%) of these patients being above their ideal weight as defined by the World Health Organization (statistical analysis not performed due to limited sample size). Johnson et al. $(\mathrm{N}=1986)$ also reported a higher risk of MBC in overweight cases $(\mathrm{OR}=2.19,95 \% \mathrm{CI}: 1.08$ - 4.43) [8].

Excessive alcohol has also been postulated to increase MBC risk as a result of its influence on hormone levels. Guenel et al. investigated the role of alcohol consumption in 74 MBC patients and 1432 age-matched controls [39]. In comparison to age- and geographically-matched controls, the risk of developing breast cancer in men increased by $16 \%$ (95\% CI: 7 - 26) per 10 grams of alcohol per day $(p<0.001)$ [39]. Additionally, an odds ratio of 5.89 (95\% CI: 2.21 - 15.69) was observed for alcohol intake greater than 90 grams per day as compared with light consumption of less than 15 grams per day, and the authors concluded that the relative risk of male breast cancer increases with consumption levels [39]. Conversely, despite a large sample size ( $\mathrm{N}=4,501,578)$ of VA patients with an admission diagnosis of alcoholism, Brinton et al. found no evidence of alteration in MBC risk in subgroup analysis, and further failed to detect an association of MBC with liver cirrhosis secondary to either alcohol consumption or other causes [34]. Similarly, Brinton et al. [7] and Casagrande et al. [35] found no evidence for a relationship between excessive alcohol consumption and increased MBC risk, and separate analyses by Ewertz et al. [10] and Sorensen et al. [40] $(\mathrm{N}=11,642)$ involving men with liver cirrhosis also failed to detect a significant increase in MBC risk.

\section{Conclusions}

Male breast cancer is an uncommon disease entity which typically presents with poor prognostic features, advanced stage, large tumor size, frequent lymphatic invasion, and early chest wall spread [3]. Large-scale epidemiologic studies have been difficult to conduct as a result of the disease's rarity. However, current published literature indicates that MBC is similar to its female counterpart clinically, in that various familial, genetic, hormonal, and environmental factors predispose at-risk populations to its development.

Public and physician awareness about male populations at risk for breast cancer is limited, if not non-existent, and men diagnosed with breast cancer are likely to suffer from psychological concerns including stigma, altered body image, lack of emotional support and feelings of isolation, and disease misperceptions [41]-[44]. As a result of poor knowledge about MBC among the public and healthcare community, there are currently no guidelines for breast cancer screening in male populations, even among those at high risk for the disease, which leads to delays in diagnosis and management. This fact, combined with data suggesting that males present with advanced stage disease, clearly implies the need for more defined screening criteria in select subgroups.

Individuals who fulfill one or more high risk criterion should be provided routine surveillance via clinical examination and imaging. Fifty to ninety percent of MBC cases present initially with a palpable breast mass [45]-[47]. This finding dictates a role for physical examination of the breast in high-risk male populations. Current National Comprehensive Cancer Network (NCCN) guidelines for men with BRCA1/2 mutations recommend that healthcare providers teach and encourage breast self-examination and perform clinical breast examinations twice a year [2]. We recommend that those guidelines be broadened to include the following five highrisk populations: 1) males with a previous personal history of breast carcinoma, 2) males with a strong family history of breast cancer (defined as an affected mother or sister), 3) confirmed BRCA2 mutation carriers (regardless of family history), 4) males with a diagnosis of Klinefelter's syndrome, and 5) males employed in the chemical manufacturing or motor vehicle industry. Mammography should serve as an additional means of screening for the aforementioned populations. Mammographic screening has proven to be greater than $90 \%$ sensitive and specific in diagnosing malignant lesions in the male breast, with a negative predictive value of 99\% for all categories of benign disease [48]. In light of this data, the five high-risk populations outlined above may benefit from annual clinical mammography in addition to bi-annual clinical examination. Lastly, there exist important management implications for BRCA2 carriers. Genetic testing for BRCA2 should be recommended for any MBC patient, regardless of family history of breast cancer, due to the large percentage of BRCA2 pathogenic mutations recorded in MBC patients lacking a family history of breast cancer.

In conclusion, select male high risk populations may benefit from routine breast cancer surveillance with bi-annual physician physical examination and yearly mammography. Public awareness of male breast cancer, particularly to those at high risk of MBC, is substantially lacking and serves as an obstacle to effective screening. Increased public and physician education on male breast cancer and the development of preventative health 
campaigns for at-risk populations should help to raise awareness about the rare disease and the need for screening of at-risk populations [47] [49]-[54].

\section{Author Disclosure Statement}

No competing financial interests exist.

\section{References}

[1] American Cancer Society (2013) Breast Cancer in Men. American Cancer Society, Inc., Atlanta.

[2] Korde, L.A., Zujewski, J.A., Karmin, L., et al. (2012) Multidisciplinary Meeting on Male Breast Cancer: Summary and Research Recommendations. Journal of Clinical Oncology, 28, 2114-2122. http://dx.doi.org/10.1200/JCO.2009.25.5729

[3] Ottini, L., Palli, D., Rizzo, S., et al. (2010) Male Breast Cancer. Critical Reviews in Oncology/Hematology, 73, 141155. http://dx.doi.org/10.1016/j.critrevonc.2009.04.003

[4] Friedman, L.S., Gayther, S.A., Kurosaki, T., et al. (1997) Mutation Analysis of BRCA1 and BRCA2 in a Male Breast Cancer Population. The American Journal of Human Genetics, 60, 313-319.

[5] Rosenblatt, K.A., Thomas, D.B., McTiernan, A., et al. (1991) Breast Cancer in Men: Aspects of Familial Aggregation. Journal of the National Cancer Institute, 83, 849-854. http://dx.doi.org/10.1093/jnci/83.12.849

[6] Haraldsson, K., Loman, N., Zhang, Q.X., et al. (1996) BRCA2 Germ-Line Mutations Are Frequent in Male Breast Cancer Patients without a Family History of the Disease. Cancer Research, 58, 1367-1371.

[7] Brinton, L.A., Richesson, D.A., Gierach, G.L., et al. (2008) Prospective Evaluation of Risk Factors for Male Breast Cancer. Journal of the National Cancer Institute, 100, 1477-1481. http://dx.doi.org/10.1093/jnci/djn329

[8] Johnson, K.C., Pan, S. and Mao, Y. (2002) Risk Factors for Male Breast Cancer in Canada, 1994-1998. European Journal of Cancer Prevention, 11, 253-263. http://dx.doi.org/10.1097/00008469-200206000-00009

[9] D’Avanzo, B. and La Vecchia, C. (1995) Risk Factors for Male Breast Cancer. British Journal of Cancer, 71, 13591362. http://dx.doi.org/10.1038/bjc.1995.264

[10] Ewertz, M., Holmberg, L., Tretli, S., et al. (2001) Risk Factors for Male Breast Cancer-A Case-Control Study from Scandinavia. Acta Oncologica, 40, 467-471. http://dx.doi.org/10.1080/028418601750288181

[11] Thorlacius, S., Olafsdottir, G., Tryggvadottir, L., Neuhausen, S., Jonasson, J.G., Tavtigian, S.V., Tulinius, H., Ögmundsdottir, H.M. and Eyfjörd, J.E. (1996) A Single BRCA2 Mutation in Male and Female Breast Cancer Families from Iceland with Varied Cancer Phenotypes. Nature Genetics, 13, 117-119. http://dx.doi.org/10.1038/ng0596-117

[12] Couch, F.J., Farid, L.M., DeShano, M.L., Tavtigian, S.V., Calzone, K., Campeau, L., et al. (1996) BRCA2 Germline Mutations in Male Breast Cancer Cases and Breast Cancer Families. Nature Genetics, 13, 123-125. http://dx.doi.org/10.1038/ng0596-123

[13] Young, I.E., Kurian, K.M., Mackenzie, M.A.F., Kunkler, I.H., Cohen, B.B., Hooper, M.L., Wyllie, A.H. and Steel, C.M. (2000) The CAG Repeat within the Androgen Receptor Gene in Male Breast Cancer Patients. Journal of Medical Genetics, 37, 139-140. http://dx.doi.org/10.1136/jmg.37.2.139

[14] Gudmundsdottir, K., Thorlacius, S., Jonasson, J.G., Sigfusson, B.F., Tryggvadottir, L. and Eyfjord, J.E. (2003) CYP17 Promoted Polymorphisms and Breast Cancer Risk in Males and Females in Relation to BRCA2 Status. British Journal of Cancer, 88, 933-936. http://dx.doi.org/10.1038/sj.bjc.6600839

[15] Ding, Y.C., Steele, L., Kuan, C.J., Greilac, S. and Neuhausen, S.L. (2011) Mutations in BRCA2 and PALB2 in Male Breast Cancer Cases from the United States. Breast Cancer Research and Treatment, 126, 771-778. http://dx.doi.org/10.1007/s10549-010-1195-2

[16] Csokay, B., Udvarhelyi, N., Sulyok, Z., Besznyak, I., Ramus, S., Ponder, B. and Olah, E. (1999) High Frequency of Germ-Line Brca2 Mutations among Hungarian Male Breast Cancer Patients without Family History. Cancer Research, 59, 995-998.

[17] Mavraki, E., Gray, I.C., Bishop, D.T. and Spurr, N.K. (1997) Germline RBCA2 Mutations in Men with Breast Cancer. British Journal of Cancer, 76, 1428-1431. http://dx.doi.org/10.1038/bjc.1997.574

[18] Syrjakoski, K., Kuukasjarvi, T., Waltering, K., Haraldsson, K., Auvinen, A., Borg, Å., Kainu, T., Kallioniemi, O.P. and Koivisto, P.A. (2004) BRCA2 Mutations in 154 Finnish Male Breast Cancer Patients. Neoplasia, 6, 541-545. http://dx.doi.org/10.1593/neo.04193

[19] Basham, V.M., Lipscombe, J.M., Ward, J.M., Gayther, S.A., Ponder, B.A.J., Easton, D.F. and Pharoah, P.D.P. (2002) BRCA1 and BRCA2 Mutations in a Population-Based Study of Male Breast Cancer. Breast Cancer Research, 4, R2. 
http://dx.doi.org/10.1186/bcr419

[20] Meijers-Heijboer, H., van den Ouweland, A., Kiln, J., Wasielewski, M., de Snoo, A., Oldenburg, R., et al. (2002) LowPenetrance Susceptibility to Breast Cancer Due to CHEK2*1100delC in Noncarriers of BRCA1 or BRCA2 Mutations. Nature Genetics, 31, 55-59. http://dx.doi.org/10.1038/ng879

[21] Chodick, G., Struewing, J.P., Ron, E., Rutter, J.L. and Iscovich, J. (2008) Similar Prevalence of Founder BRCA1 and BRCA2 Mutations among Ashkenazi and Non-Ashkenazi Men with Breast Cancer: Evidence from 261 Cases in Israel, 1976-1999. The European Journal of Medical Genetics, 51, 141-147. http://dx.doi.org/10.1016/j.ejmg.2007.11.001

[22] Tai, Y.C., Domchek, S., Parmigiani, G. and Chen, S.N. (2007) Breast Cancer Risk among Male BRCA1 and BRCA2 Mutation Carriers. Journal of the National Cancer Institute, 99, 1811-1814. http://dx.doi.org/10.1093/jnci/djm203

[23] Risch, H.A., McLaughlin, J.R., Cole, D.E.C., Rosen, B., Bradley, L., Fan, I., et al. (2006) Population BRCA1 and BRCA2 Mutation Frequencies and Cancer Penetrances: A Kin-Cohort Study in Ontario, Canada. Journal of the National Cancer Institute, 98, 1694-1706. http://dx.doi.org/10.1093/jnci/djj465

[24] Frank, T.S., Deffenbaugh, A.M., Reid, J.E., Hulick, M., Ward, B.E., Lingenfelter, B., et al. (2002) Clinical Characteristics of Individuals with Germline Mutations in BRCA1 and BRCA2: Analysis of 10,000 Individuals. Journal of Clinical Oncology, 20, 1480-1490. http://dx.doi.org/10.1200/JCO.20.6.1480

[25] National Cancer Institute (2013) Genetics of Breast and Ovarian Cancer (PDQ). http://www.cancer.gov/cancertopics/pdq/genetics/breast-and-ovarian/HealthProfessional/page2

[26] Ottini, L., Rizzolo, P., Zanna, I., Falchetti, M., Masala, G., Ceccarelli, K., et al. (2009) BRCA1/BRCA2 Mutation Status and Clinical-Pathologic Features of 108 Male Breast Cancer Cases from Tuscany: A Population-Based Study in Central Italy. Breast Cancer Research and Treatment, 116, 577-586. http://dx.doi.org/10.1007/s10549-008-0194-z

[27] Malone, K.E., Daling, J.R., Doody, D.R., Hsu, L., Bernstein, L., Coates, R.J., et al. (2006) Prevalence and Predictors of BRCA1 and BRCA2 Mutations in a Population-Based Study of Breast Cancer in White and Black American Women Ages 35 to 64 Years. Cancer Research, 66, 8297. http://dx.doi.org/10.1158/0008-5472.CAN-06-0503

[28] McLaughlin, J.K., Malker, H.S.R., Blot, W.J., Weiner, J.A., Ericsson, J.L. and Fraumeni, J.F. (1988) Occupational Risks for Male Breast Cancer in Sweden. British Journal of Industrial Medicine, 45, 275-276.

[29] Sun, J.W., Li, X.R., Gao, H.Y., Yin, J.Y., Qin, Q., Nie, S.F. and Wei, S. (2013) Electromagnetic Field Exposure and Male Breast Cancer Risk: A Meta-Analysis of 18 Studies. Asian Pacific Journal of Cancer Prevention, 14, 523-528. http://dx.doi.org/10.7314/APJCP.2013.14.1.523

[30] Cocco, P., Figgs, L., Dosemeci, M., Hayes, R., Linet, M.S. and Hsing, A.W. (1998) Case-Control Study of Occupational Exposures and Male Breast Cancer. Occupational and Environmental Medicine, 55, 599-604. http://dx.doi.org/10.1136/oem.55.9.599

[31] Villeneuve, S., Cyr, D., Lynge, E., Orsi, L., Sabroe, S., Merletti, F., et al. (2010) Occupation and Occupational Exposure to Endocrine Disrupting Chemicals in Male Breast Cancer: A Case-Control Study in Europe. Occupational and Environmental Medicine, 67, 837-844. http://dx.doi.org/10.1136/oem.2009.052175

[32] Hansen, J. (2000) Elevated Risk for Male Breast Cancer after Occupational Exposure to Gasoline and Vehicular Combustion Products. American Journal of Industrial Medicine, 37, 349-352. http://dx.doi.org/10.1002/(SICI)1097-0274(200004)37:4<349::AID-AJIM4>3.0.CO;2-L

[33] Nirmul, D., Pegoraro, R.J., Jialal, I., Naidoo, C. and Joubert, S.M. (1982) The Sex Hormone Profile of Male Patients with Breast Cancer. British Journal of Cancer, 48, 423-427. http://dx.doi.org/10.1038/bjc.1983.208

[34] Brinton, L.A., Carreon, J.D., Gierach, G.L., McGlynn, K.A. and Gridley, G. (2010) Etiologic Factors for Male Breast Cancer in the U.S. Veterans Affairs Medical Care System Database. Breast Cancer Research and Treatment, 119, 185192. http://dx.doi.org/10.1007/s10549-009-0379-0

[35] Casagrande, J.T., Hanisch, R., Pike, M.C., et al. (1988) A Case-Control Study of Male Breast Cancer. Cancer Research, 48, 1326-1330.

[36] Hsing, A.W., McLaughlin, J.K., Cocco, P., Co Chien, H.T. and Fraumeni Jr., J.F. (1998) Risk Factors for Male Breast Cancer (United States). Cancer Causes and Control, 9, 269-275. http://dx.doi.org/10.1023/A:1008869003012

[37] Olsson, H., Bloodstream, A. and Alm, P. (2002) Male Gynecomastia and Risk for Malignant Tumors—A Cohort Study. BMC Cancer, 2, 26.

[38] Altinli, E., Gorgun, E., Karabicak, I., Uras, C., Unal, H. and Akcal, T. (2002) Anthropometric Measurements in Male Breast Cancer. Obesity Surgery, 12, 869-870. http://dx.doi.org/10.1381/096089202320995727

[39] Guenel, P., Cyr, D., Sabroe, S., Lynge, E., Merletti, F., Ahrens, W., et al. (2004) Alcohol Drinking May Increase Risk of Breast Cancer in Men: A European Population-Based Case-Control Study. Cancer Causes and Control, 15, 571-580. http://dx.doi.org/10.1023/B:CACO.0000036154.18162.43

[40] Sorensen, H.T., Friis, S., Olsen, J.H., Thulstrup, A.M., Mellemkjaer, L., Linet, M., Trichopoulos, D., Vilstrup, H. and 
Olsen, J. (1998) Risk of Breast Cancer in Men with Liver Cirrhosis. American Journal of Gastroenterology, 93, 231233. http://dx.doi.org/10.1111/j.1572-0241.1998.00231.x

[41] Al-Naggar, R.A. and Al-Naggar, D.H. (2012) Perceptions and Opinions about Male Breast Cancer and Male Breast Self-Examination: A Qualitative Study. Asian Pacific Journal of Cancer Prevention, 13, 243-246. http://dx.doi.org/10.7314/APJCP.2012.13.1.243

[42] Bunkley, D.T., Robinson, J.D., Bennett Jr., N.E. and Gordon, S. (2000) Breast Cancer in Men: Emasculation by Association? Journal of Clinical Psychology in Medical Settings, 7, 91-97. http://dx.doi.org/10.1023/A:1009553613564

[43] France, L., Michie, S., Barrett-Lee, P., Brain, K., Harper, P. and Gray, J. (2000) Male Cancer: A Qualitative Study of Male Breast Cancer. The Breast, 9, 343-348. http://dx.doi.org/10.1054/brst.2000.0173

[44] Nicholas, D.R. (2000) Men, Masculinity, and Cancer: Risk-Factor Behaviors, Early Detection, and Psychosocial Adaptation. Journal of American College Health, 49, 27-33. http://dx.doi.org/10.1080/07448480009596279

[45] Kiluk, J.V., Lee, M.C., Park, C.K., Meade, T., Minton, S., Harris, E., Kim, J. and Laronga, C. (2011) Male Breast Cancer: Management and Follow-Up Recommendations. The Breast Journal, 17, 503-509. http://dx.doi.org/10.1111/j.1524-4741.2011.01148.x

[46] Haché, K.D., Gray, S., Barnes, P.J., Dewar, R., Younis, T. and Rayson, D. (2007) Clinical and Pathological Correlations in Male Breast Cancer: Intratumoral Aromatase Expression via Tissue Microarray. Breast Cancer Research and Treatment, 105, 169-175. http://dx.doi.org/10.1007/s10549-006-9448-9

[47] Dershaw, D.D., Borgen, P.I., Deutch, B.M. and Liberman, L. (1993) Mammographic Findings in Men with Breast Cancer. American Journal of Roentgenology, 160, 267-270. http://dx.doi.org/10.2214/ajr.160.2.8424331

[48] Evans, G.F.F., Anthony, T., Appelbaum, A.H., Schumpert, T.D., Levy, K.R., Amirkhan, R.H., Cambell, T.J., Lopez, J. and Turnage, R.H. (2001) The Diagnostic Accuracy of Mammography in the Evaluation of Male Breast Disease. American Journal of Surgery, 181, 96-100. http://dx.doi.org/10.1016/S0002-9610(00)00571-7

[49] Brenner, R.J., Weitzel, J.N., Hansen, N. and Boasberg, P. (2004) Screening-Detected Breast Cancer in a Man with BRCA2 Mutation: Case Report. Radiology, 230, 553-555. http://dx.doi.org/10.1148/radiol.2302030360

[50] Estala, S.M. (2006) Proposed Screening Recommendations for Male Breast Cancer. The Nurse Practitioner, 31, 62-63. http://dx.doi.org/10.1097/00006205-200602000-00012

[51] Freedman, B.C., Keto, J. and Rosenbaum Smith, S.M. (2012) Screening Mammography in Men with BRCA Mutations: Is There a Role? The Breast Journal, 18, 73-75. http://dx.doi.org/10.1111/j.1524-4741.2011.01185.X

[52] Patterson, S.K., Helvie, M.A., Aziz, K. and Nees, A.V. (2006) Outcome of Men Presenting with Clinical Breast Problems: The Role of Mammography and Ultrasound. The Breast Journal, 12, 418-423. http://dx.doi.org/10.1111/j.1075-122X.2006.00298.x

[53] Dershaw, D.D. (1986) Male Mammography. American Journal of Roentgenology, 146, 127-131. http://dx.doi.org/10.2214/ajr.146.1.127

[54] Ruddy, K.J. and Winer, E.P. (2013) Male Breast Cancer: Risk Factors, Biology, Diagnosis, Treatment, and Survivorship. Annals of Oncology, 24, 1434-1443. http://dx.doi.org/10.1093/annonc/mdt025 
Scientific Research Publishing (SCIRP) is one of the largest Open Access journal publishers. It is currently publishing more than 200 open access, online, peer-reviewed journals covering a wide range of academic disciplines. SCIRP serves the worldwide academic communities and contributes to the progress and application of science with its publication.

Other selected journals from SCIRP are listed as below. Submit your manuscript to us via either submit@scirp.org or Online Submission Portal.
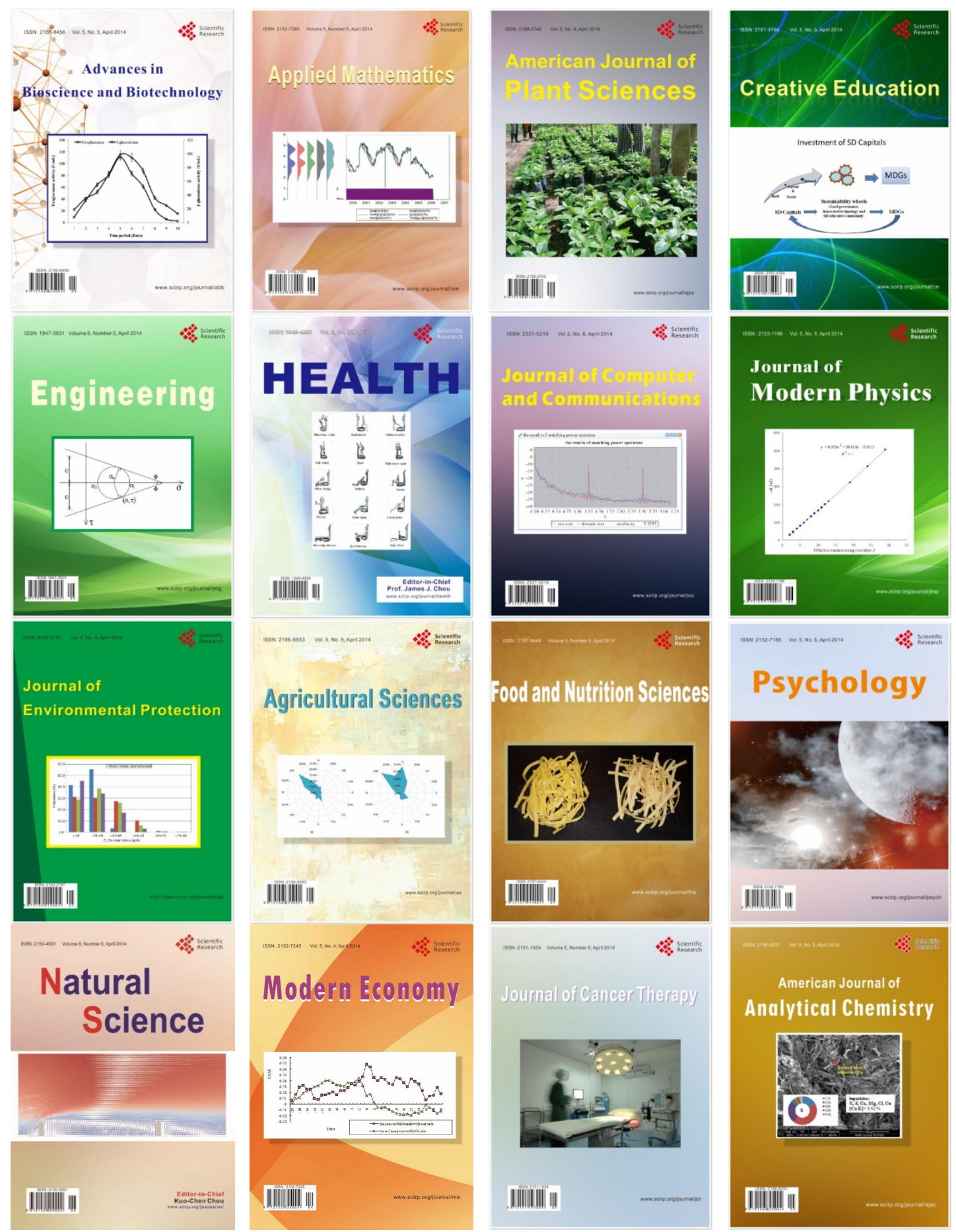